\title{
ENVIRONMENTAL VARIABLES AND QUALITY TOOLS APPLIED TO THE OPERATOR OF AN AGRICULTURAL MICROTRACTOR
}

\author{
Francisca N. de L. Estevam ${ }^{1 *}$, Renata F. de Queiroz², André F. Damasceno², \\ Rouverson P. da Silva ${ }^{2}$, Murilo A. Voltarelli ${ }^{3}$, José A. D. Barbosa Filho ${ }^{4}$
}

1* Corresponding author. Universidade Estadual Paulista "Júlio de Mesquita Filho" - FCAV/ Unesp/ Jaboticabal- SP, Brasil.
E-mail: nivanda_lima@hotmail.com | ORCID ID: https://orcid.org/0000-0002-0667-348X

\section{KEYWORDS}

operator health, thermal load, ergonomics

\begin{abstract}
Work in the field is characterized as unstructured because it is performed in inconvenient postures, without a fixed workstation, exposing the worker directly to the sun and other inclement weather. This may interfere in the health and the performance of the activity. The objective of this work was to characterize the environment of the agricultural microtractor operator, evaluating the thermal comfort during the activity in the municipality of Quixadá, CE. A model TC14 Super Yanmar Agritech microtractor, coupled to a rotary spindle, was used. For the measurements of the environmental variables, sensors and devices were installed on the operator and in the microtractor. The experimental design adopted the assumptions of statistical quality control. Fifteen collections were done daily at different times for three consecutive days. The data obtained were indices of thermal discomfort and thermography, both of which were analyzed by sequential graphs (run charts), control graph (Xbar-R chart), and scatter plot. At all rates, the work performed proved to be inadequate, exceeding the operator's capabilities and limitations. It was concluded that the activity performed by the microtractor operator is stressful. Measures should be taken to improve working conditions without affecting the operator's health.
\end{abstract}

\section{INTRODUCTION}

The environment of agricultural work involves activity in open air subject to diverse weather conditions. According to Gosling \& Araújo (2008), agricultural activity represents one of the main sectors of the economy of Brazil. The rural worker is fundamental in the productive process, making it indispensable to study the health and safety of these workers under the various types of occupational hazard to which they are exposed.

Thermal stress hampers the work activity of rural workers who carry out heavy activities associated with poor conditions, which can cause serious illness or even lead to death (Roscani et al., 2017). During physical activity, be it labor or not, the production of heat in the body increases. At such times, even with thermoregulatory mechanisms, high ambient temperatures can lead to heat stress and cause common pathologies, which do not compromise the thermoregulatory system, such as syncope and heat edema, and may cause pathologies that require emergency care, such as dehydration and hyperthermia (Camargo \& Furlan, 2011).

Thermography is a technique used to distinguish the different temperatures located in areas of a region or a body. Its wide application makes it possible to use this tool in several areas that are currently being used in animal production (Chacur et al., 2016). Infrared thermography has been a successful tool for estimating the surface temperature of several species (Kotrba et al., 2007; Montanholi et al., 2008). According to Gade \& Moeslund (2014), infrared thermographic cameras have advantages over other technologies because they make it easy to capture images, and there is no need to contact the target - it is a noninvasive and painless practice. The generated images are twodimensional and make possible the comparison of the temperatures in different areas in the same image, and they do not cause side effects.

In the context of mechanized agricultural operations, it is important to seek to execute processes within preestablished standards and norms, stabilizing and increasing

\footnotetext{
${ }^{2}$ Universidade Estadual Paulista "Júlio de Mesquita Filho" - FCAV/ Unesp/ Jaboticabal- SP, Brasil.

${ }^{3}$ Universidade Federal de São Carlos/ Buri - SP, Brasil.

${ }^{4}$ Universidade Federal do Ceará/ Fortaleza - CE, Brasil.

Received in: 12-13-2017
}

Accepted in: 1-21-2019 
the reliability and quality of products and processes (Barros \& Milan, 2010). The evaluation of the operational performance of tractors and implements is of paramount importance for both the management of machinery and the manufacturer (Ranjbarian et al., 2017). By means of statistical process control (SPC) and its tools, it is possible to analyze the quality of an operation, associating process variability with quality in an antagonistic way (Noronha et al., 2011; Zerbato et al., 2014).

Silva et al. (2015) argued that, for the success of agricultural operations, it is necessary to control and maintain quality by determining all factors that influence agricultural processes, and factor management increases productivity by reducing costs. The use of statistical process control in agricultural operations is an important statistical tool for solving problems, enabling the monitoring of processes and assisting in the decision making in mechanized agricultural operations.

In quality operations improvement, quality control tools are used in process monitoring. In this context, SPC covers data collection and the analysis and interpretation of data for solving a particular problem (Paranthaman, 1990).

The objective of this work was to evaluate the interference of environmental conditions in the occurrence of thermal stress in the agricultural microtractor operator during activity, using statistical control tools and a thermal comfort index in the Quixadá, CE region.

\section{MATERIAL AND METHODS}

The work was carried out at the Fazenda Experimental Lavoura Seca of the Federal University of Ceará located in the municipality of Quixadá, central hinterland of Ceará, $168 \mathrm{~km}$ from Fortaleza, at $4^{\circ} 59^{\prime} \mathrm{S}$ latitude, $39^{\circ} 01^{\prime} \mathrm{W}$ longitude of Greenwich, altitude of 190 $\mathrm{m}$. The period of data collection corresponded to the end of April and beginning of May, the climate of the region, according to Köppen (1918), is hot and semiarid with an air temperature ranging from $24{ }^{\circ} \mathrm{C}$ to $28{ }^{\circ} \mathrm{C}$, relative humidity of $70 \%$, and average annual precipitation of $838.1 \mathrm{~mm}$ (IPECE, 2018).

The periodic soil preparation was performed with a rotary hoe coupled to a Yanmar Agritech model TC14 Super four-stroke diesel engine with a power of $10.3 \mathrm{~kW}(14 \mathrm{hp})$ and a weight of $433 \mathrm{~kg}$.

The experimental design was completely randomized, with 15 working hours and 3 replicates. Temperature, humidity, and thermography data were collected at the beginning, middle and end of $1 \mathrm{~h}$ of consecutive work distributed in five different shifts, totaling 15 data collections on three consecutive days $(6: 00,6: 30,7$ : $00,8: 00,8: 30,9: 00,11: 00$, and 11:30 a.m. and 12:00, 2:00, 2:30, 3:00, 4:00, 4:30, and 5:00 p.m.). To evaluate the thermal conditions to which the operator was exposed during the execution of the activity, a HOBO meteorological miniature Pro v2 Data Logger model was installed in the microtractor for temperature collection and humidity (Figure 1).

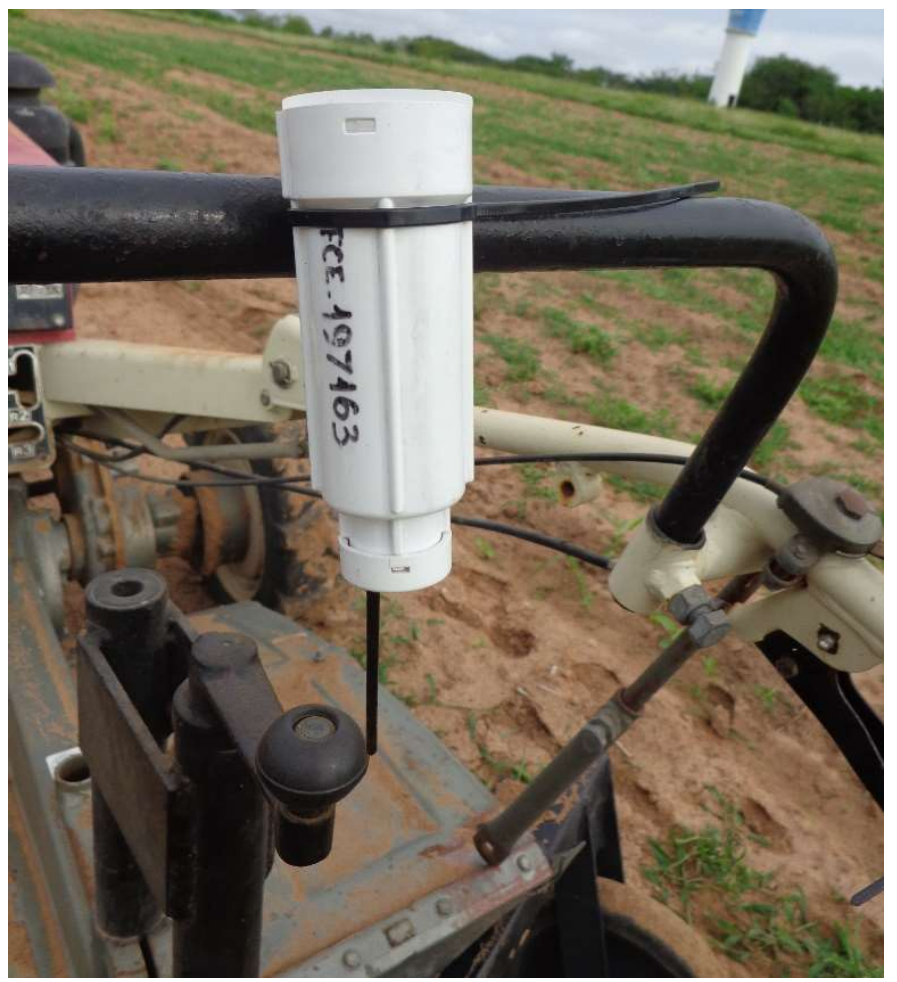

FIGURE 1. Mini Weather Station HOBO Pro v2 Datalogger installed in the microtractor

The thermal discomfort index (TDI) was analyzed by an equation proposed by Giles et al. (1990) (Equation 1). The wind velocity data were also collected locally by means of the INSTRUTERM thermal stress meter TGD-400.

$$
T D I=A T-0,55 *[(1-0,01 * R U) *(A T-14,5)]
$$

Where,

TDI: thermal discomfort index $\left({ }^{\circ} \mathrm{C}\right)$

AT: air temperature $\left({ }^{\circ} \mathrm{C}\right)$

RU: relative humidity (\%) 
The thermography was obtained with a FLIR thermometer, model i3, emissivity of 0.98 recommended for human skin and positioned at a distance of $1.0 \mathrm{~m}$ from the target.

The results were submitted to the Ryan-Joiner normality test to ascertain the normality of the data and/or the need for transformation. To analyze the quality of the process, statistical quality control tools were used: run charts, graphs to identify possible special causes of variation by monitoring the data over time, subgroup analysis control graphs (Xbar-R) representing the average of the three-day data collection process, and a dispersion diagram to evaluate the possible correlation of the variable TDI and thermography.

\section{RESULTS AND DISCUSSION}

The normal parameters of the discomfort and thermography index data showed a normal distribution according to the Ryan-Joiner test, as shown in Figures 2 and 3 .

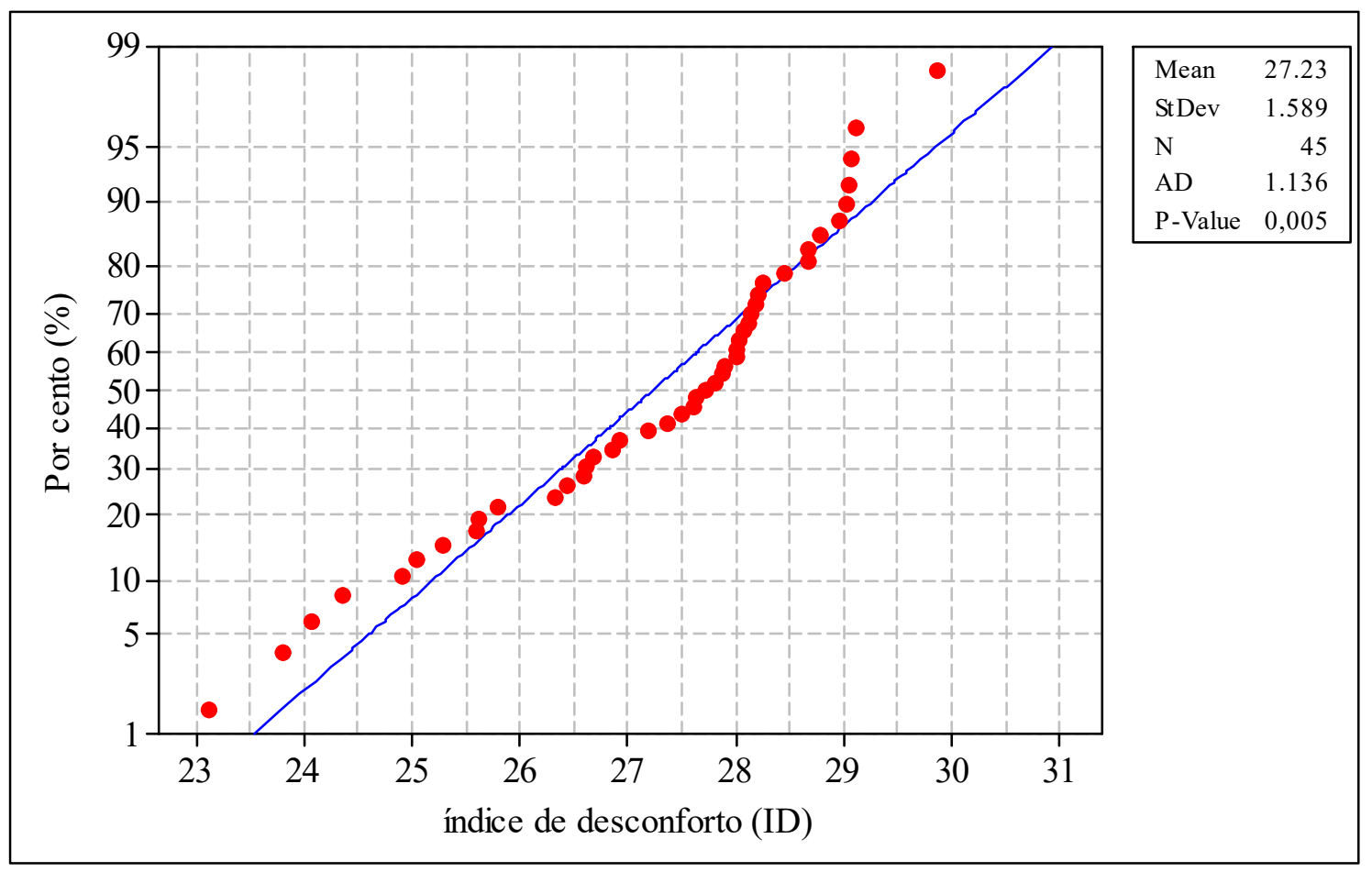

FIGURE 2. Ryan-Joiner test for thermal discomfort index.

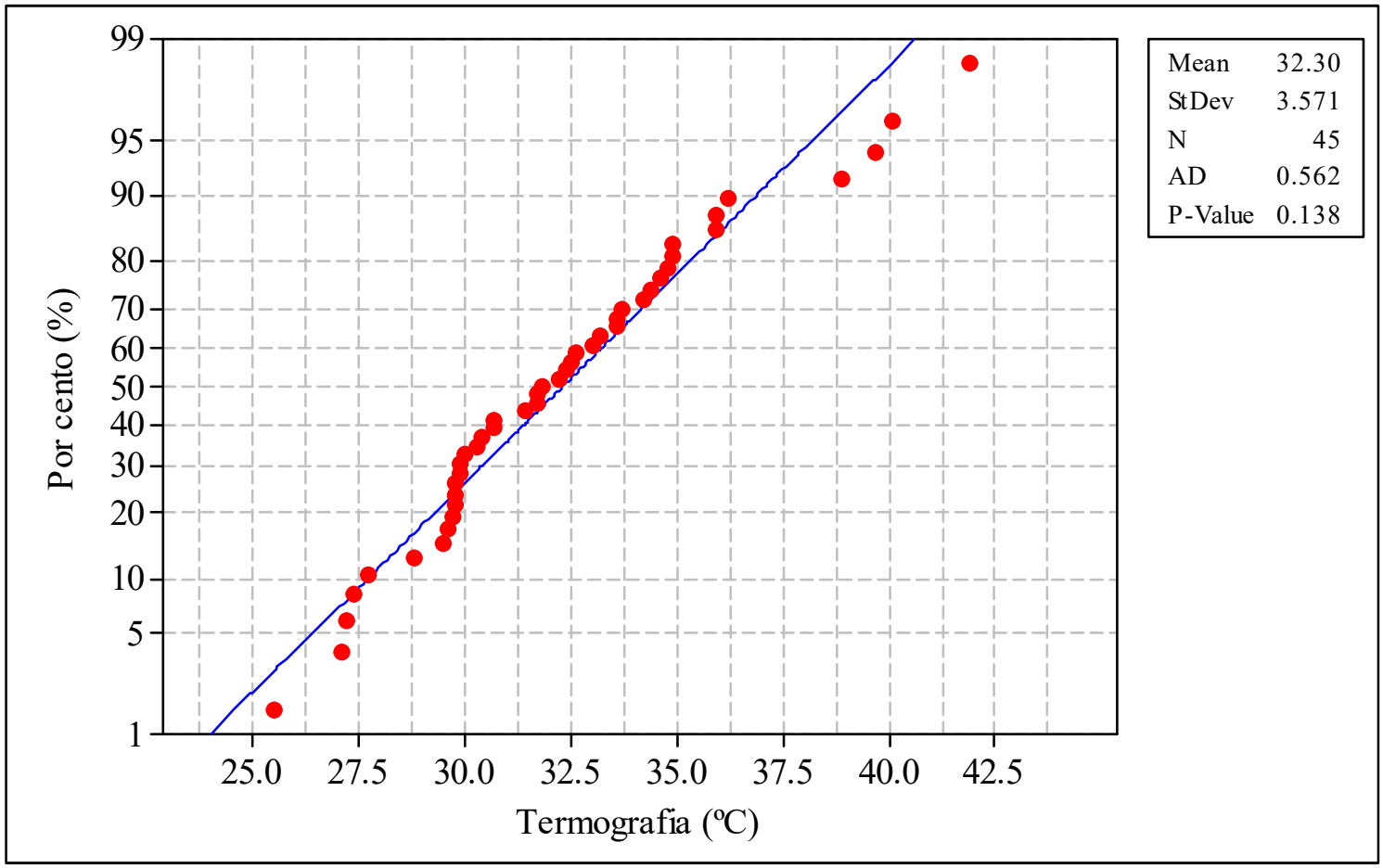

FIGURE 3. Ryan-Joiner test for thermography. 
According to the run chart graph for TDI, the standards established in the analysis point to clustering patterns and an upward trend indicating a variation resulting from special causes and characteristic of the gradual change of environmental conditions. The data point to the existence of a nonrandom pattern, indicating the occurrence of special causes of variation (Figure 4).

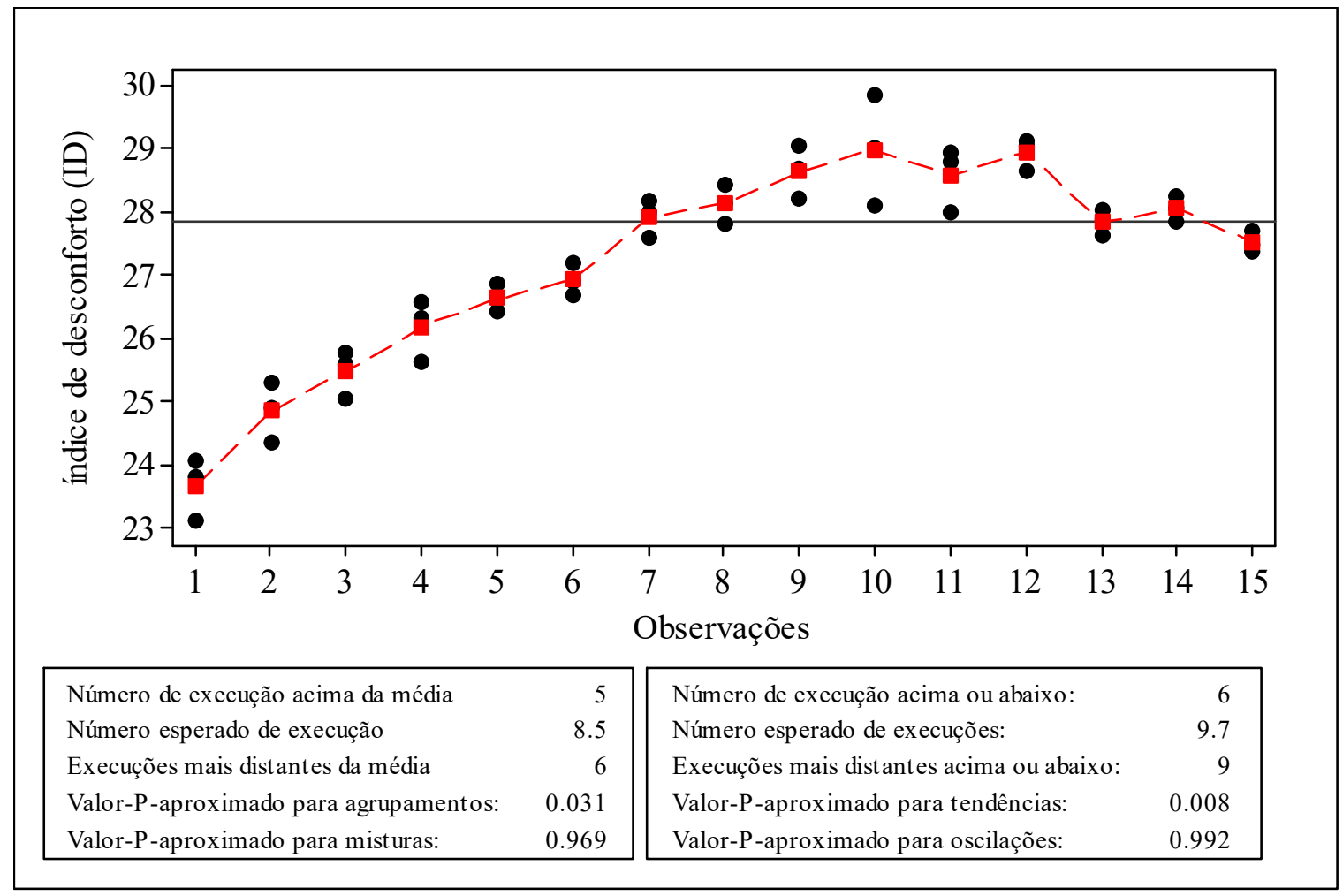

FIGURE 4. Sequential thermal discomfort index (run chart).

There is a tendency to increase the discomfort rate as the hours increase. According to Figure 5, the sequential graph for thermography presents a random behavior, indicating possible common causes of variation. The variation was inherent in the operator's own organism, which thermoregulates its temperature, even in adverse conditions.

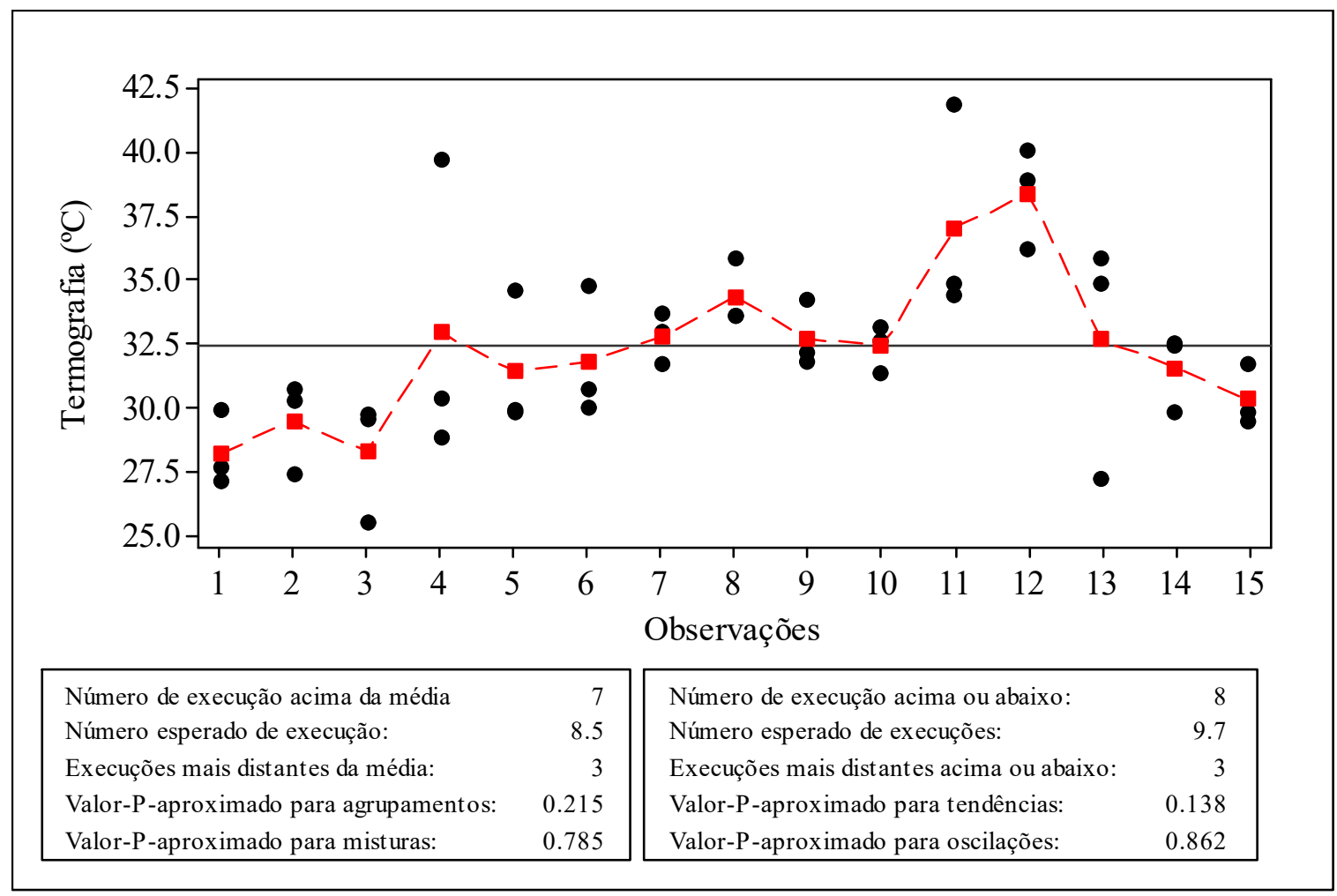

FIGURE 5. Sequential thermography chart (run chart). 
The discomfort index presented instability over the hours, characterizing a variability of the data and the low quality of the same ones according to the premises that define the statistical control of quality. It was observed, according to the graph presented in Figure 6, only five points within the lower and upper control limits.
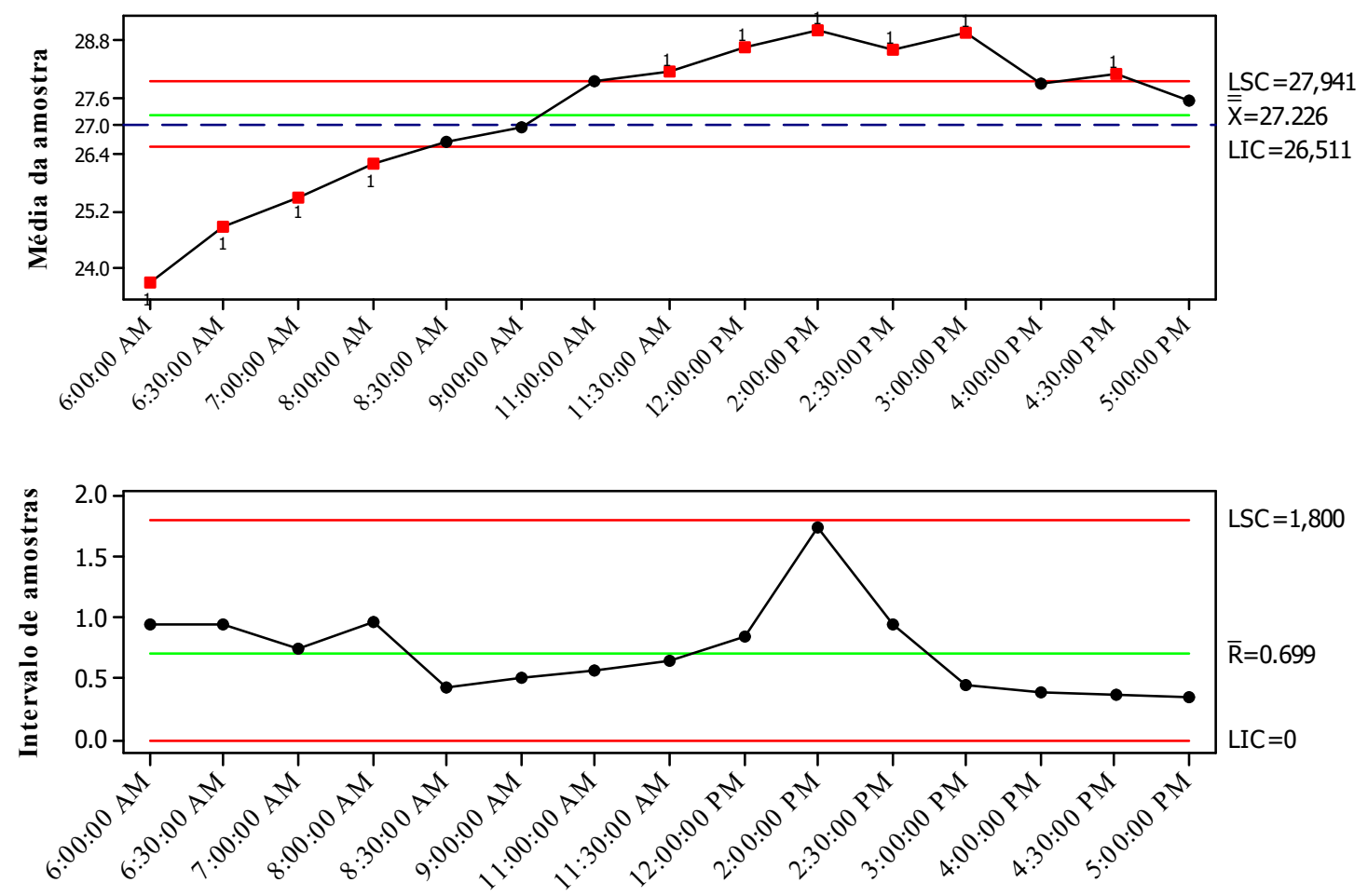

FIGURE 6. Sequential graph (Xbar-R) of discomfort index.

The lowest temperatures recorded in the day presented values of more than $24^{\circ} \mathrm{C}$, which, according to Guiles (1990), can cause discomfort in approximately 50\% of the population. However, specific values of control were adopted at $27{ }^{\circ} \mathrm{C}$. According to Guiles (1990), from this temperature, the majority of the population shows relative discomfort and a deterioration of psychophysical conditions. Two-thirds of the observed points are above the specific limit. These increase throughout the day, showing a small decrease after $16 \mathrm{~h}$, not enough to reach below the specific values. In the municipality of Quixadá, $\mathrm{CE}$, the average annual temperature is $28.2^{\circ} \mathrm{C}$, the average of the maximum is $33.4{ }^{\circ} \mathrm{C}$, and the average of the minimum is $22.9{ }^{\circ} \mathrm{C}$ (INMET, 2015). For an activity in adequate conditions of thermal comfort in the semiarid region of Ceará, the operation of the microtractor should occur between the first hours of the day and 9:00 a.m.

A low incidence of winds with a speed of $1 \mathrm{~km} \mathrm{~h}-1$ was observed, a fact that aggravates the condition of thermal stress by heat throughout the day, mainly in hours of higher temperatures. In regions with a hot climate, the absence or low incidence of winds is not desirable, according to Pallotta et al. (2015), and the wind or the lack of it can be a limiting factor for the comfort of the individual. Mallick
(1996) says that the comfort zone is intrinsically related to air velocity. The air flow over the skin causes the sensation of cooling in environments with temperatures of $30{ }^{\circ} \mathrm{C}$ or more, similar to the environmental conditions of the present experiment.

According to the collected data of temperature and humidity, it can be affirmed that the working environment of the operator in the climate of the city of Quixadá provides a condition of thermal stress by heat, because, in all the days of collection, the temperature surpassed $25^{\circ} \mathrm{C}$. Costa et al. (2010) emphasized that, in situations where the temperature is approximately $26{ }^{\circ} \mathrm{C}$ and air humidity between $65 \%$ and $68 \%$, it is possible to verify conditions of discomfort.

According to Terjung (2000), temperatures that exceed $30{ }^{\circ} \mathrm{C}$ characterize high thermal stress. When temperatures exceed $30{ }^{\circ} \mathrm{C}$ and relative humidity is approximately $50 \%$ to $70 \%$, the human body's thermal sensation is approximately $32.2{ }^{\circ} \mathrm{C}$ to $35{ }^{\circ} \mathrm{C}$, and, when it exceeds $35^{\circ} \mathrm{C}$, the thermal sensation varies from $38.8^{\circ} \mathrm{C}$ to $42.2^{\circ} \mathrm{C}$.

The thermographic images present the operator surface temperatures according to the evaluated target contrasting with the entire target environment according to the thermographic sensor capture (Figure 7). 


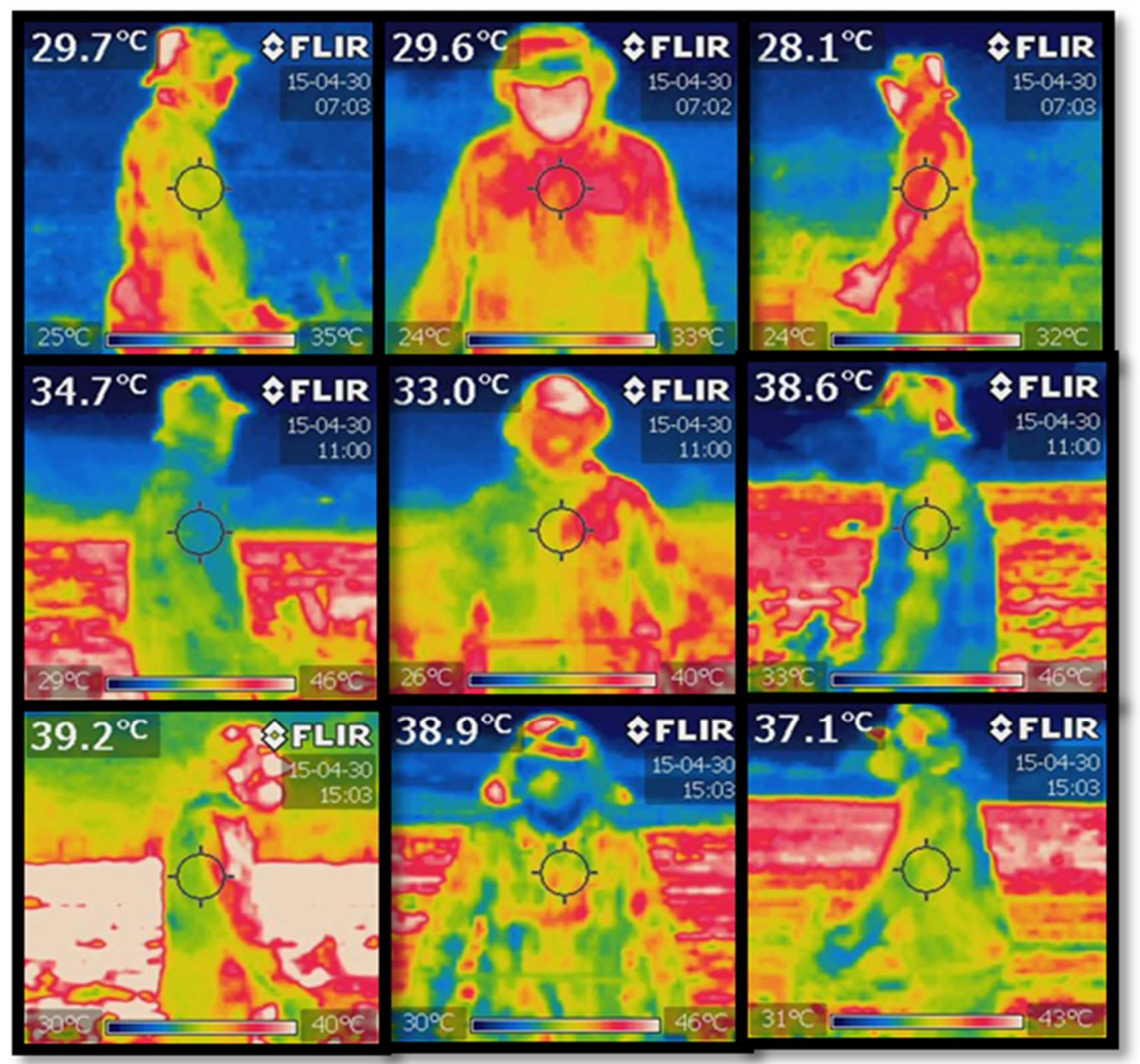

FIGURE 7. Thermography at different times of day.

The contrast of the operator's and ambient temperatures is observed in the images taken. In the first hours of the day, the temperature of the operator is above the temperature found in the environment. As the hours of the day pass, the surface temperature of the operator increases; however, the contrast between the operator and the environment is changing. The surface temperature of the environment becomes much larger than that of the operator. According to Roscani et al. (2017), exposure of the worker to heat combined with excessive physical exertion increases the risk of health hazards, and the normally uncomfortable clothing for this type of activity becomes an obstacle to the operator's heat exchanges with the environment.

According to Almeida \& Veiga (2010), the climate of the region is the determinant in the quality of body thermoregulation, making it necessary to consider the environment and the climate of the locality.

Evaluating the quality graph of the thermography, only one discrepant point from the others is observed, and it can be called a nonrandom-cause effect (Figure 8). 

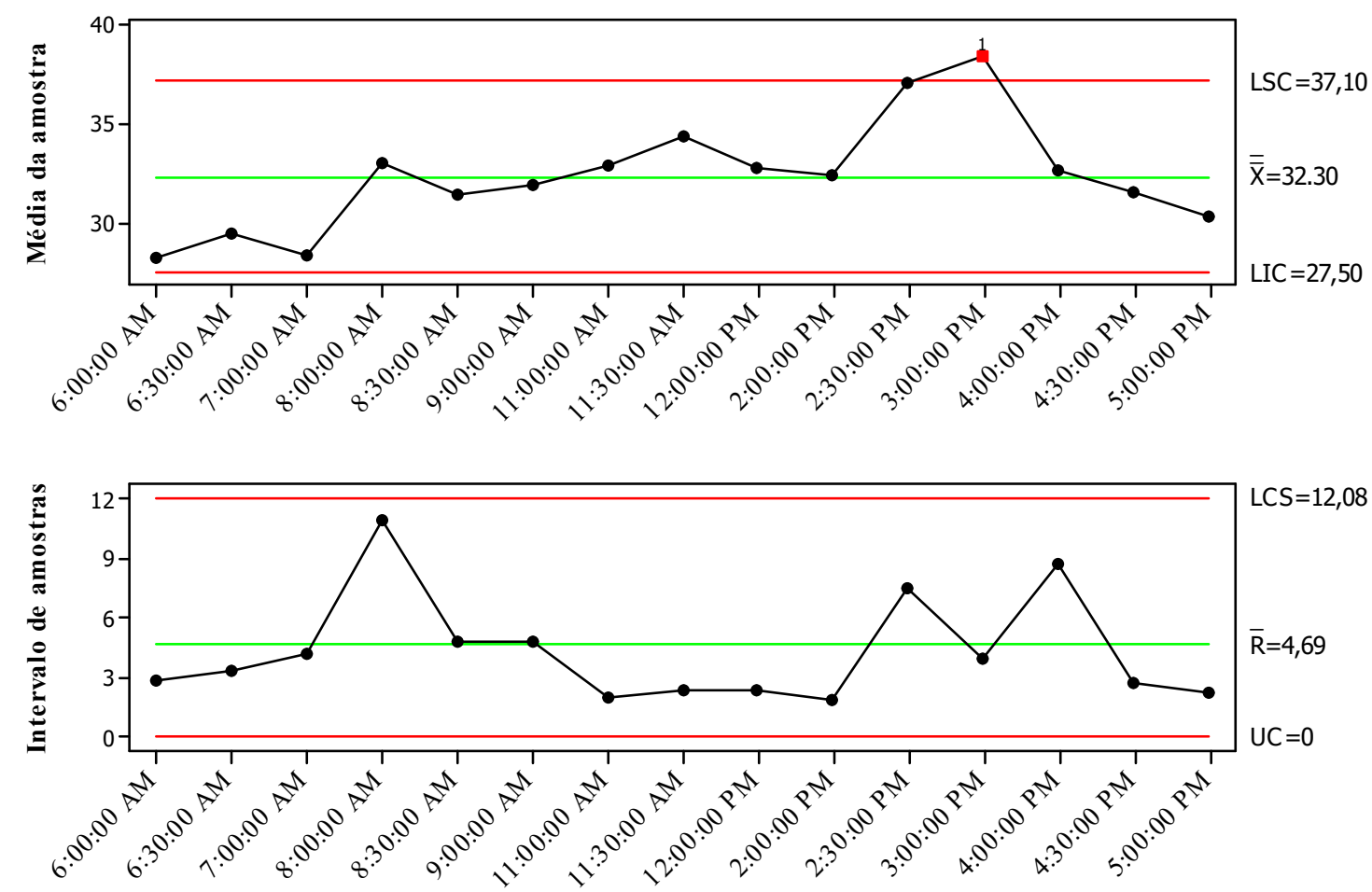

FIGURE 8. Sequential thermography (Xbar-R).

Points show a growing trend around the center line, and the average graph has a point outside the control limit, perhaps explained by the high temperature at this time. The TDI graph (Figure 6) shows that this point corresponds to the point of greater discomfort index. It is normal for the average amplitude of the thermography to be smaller than that found in the ID, because the human regulates the body temperature as we are homeothermic beings.

When heat exchanges between the human body and the environment occur without much effort, the sensation of the individual is of thermal comfort, and the individual's ability to work is maximum. The thermal discomfort caused by a heat wave, or excessive cold causes a decrease of worker's performance, overloading the body and causing dissatisfaction (Barbhuiya \& Barbhuiya 2013).

Hot and humid environments with temperature values of $32{ }^{\circ} \mathrm{C}$ and relative air humidity of more than $60 \%$ may alter heart rate, body temperature, and blood pressure (Shi et al., 2013).

The behavior of the variable index of discomfort in relation to thermography is presented in the dispersion diagram in Figure 9.

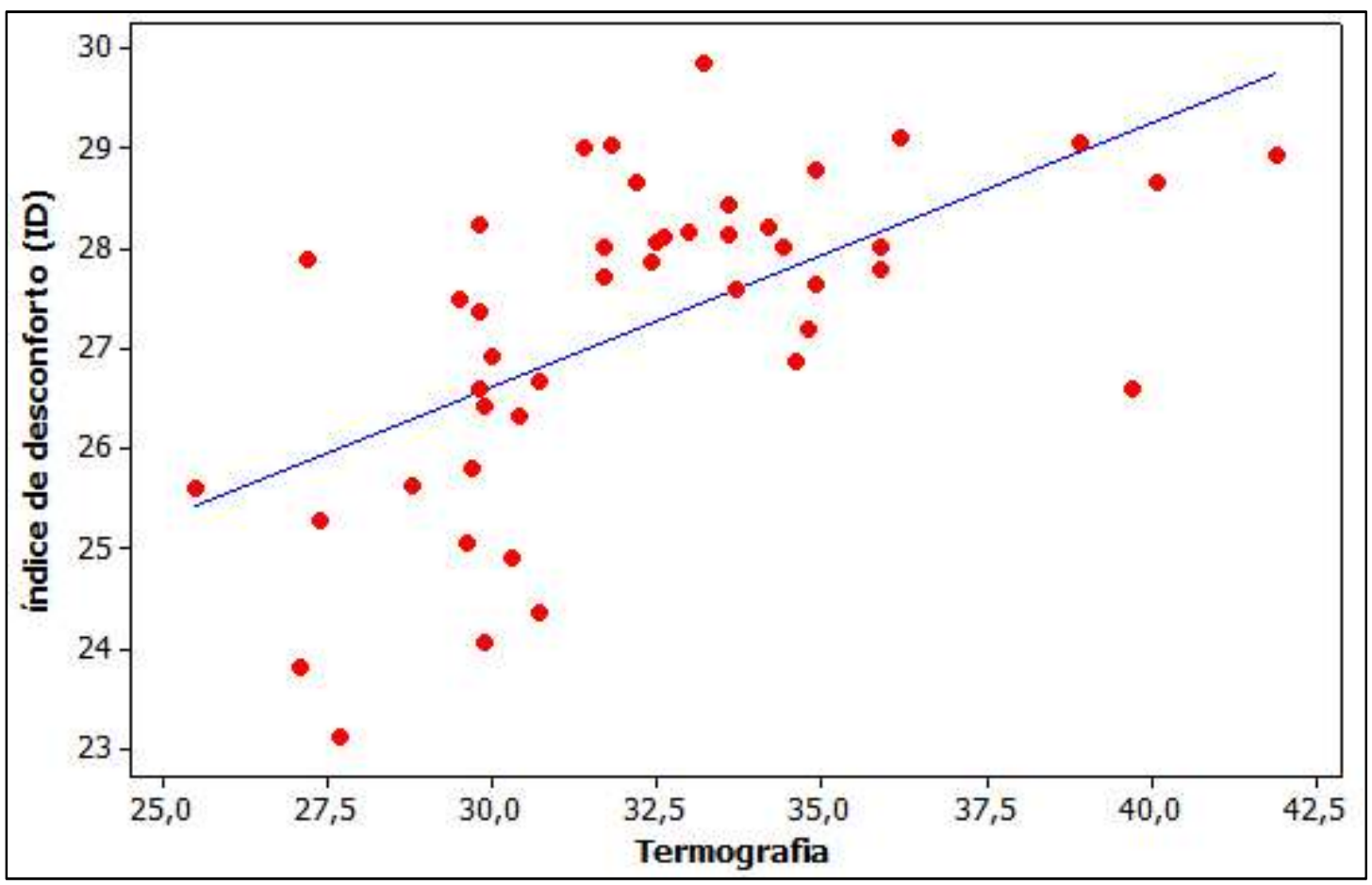

FIGURE 9. Scatterplot of TDI and thermography. 
Analyzing the diagram, it is possible to observe that there is no correlation between the variables, i.e., the operator's surface temperature is not related to the TDI. This reinforces the statement that body temperature follows self-regulation in relation to ambient temperature.

\section{CONCLUSIONS}

1. Environmental variables in the municipality of Quixadá, CE make microtractor operation stressful for the operator, so operation should only be performed until 9:00 a.m. or with regular intervals of rest.

2. High temperatures and low wind speed are factors that further aggravate heat stress conditions.

3. Statistical process control tools have proved effective for diagnosis in the prevention and detection of thermal stress conditions of the operator, making it possible to draw up an alternative strategy that reduces the impact of environmental conditions on the operator.

\section{REFERENCES}

Almeida RACS, Veiga MM (2010) Processo de trabalho rural e EPI's: discussão sobre termorregulação corporal. Revista P\&D em Engenharia de Produção 8(02):29-39.

Barbhuiya S, Barbhuiya S (2013) Thermal comfort and energy consumption in a UK educational building. Building and Environment 68:1-11. DOI: https://doi.org/10.1016/j.buildenv.2013.06.002

Barros FF, Milan M (2010) Qualidade operacional do plantio de cana-de-açúcar. Bragantia 69(1):221-29.

Camargo MG, Furlan MMDP (2011) Resposta fisiológica do corpo às temperaturas elevadas: exercício, extremos de temperatura e doenças térmicas. Saúde e Pesquisa 4(2):278-288.

Chacur MGM, Souza CD, Andrade IB, Bastos GP, Deak FLG, Souza MGR, Cornacini GF, Marques Júnior AP (2016) Aplicações da termografia por infravermelho na reprodução animal e bem-estar em animais domésticos e silvestres. Revista Brasileira de Reprodução Animal 40(3):88-94.

Costa ER, Sartoni MGB, Fantini V (2010) Análise do conforto térmico do Parque Itaimbé-Santa Maria/rs sob condições atmosféricas de domínio da massa Polar velha em situação sazonal de primavera. Geografia: Ensino \& Pesquisa 14(2):16-26.

Gade R.; Moeslund TB (2014) Thermal cameras and applications: A survey. Machine Vision and Applications 25(1):245-262.

Giles BD, Balafoutis C, Maheros P (1990) Too hot for comfort: the heatwaves in Greece in 1987 and 1988. International Journal Biometeorology 34(2):98-104.

Gosling M, Araújo GCD (2008) Saúde física do trabalhador rural submetido a ruídos e à carga térmica: um estudo em operadores de tratores. O Mundo da Saúde 32(3):275-86.
INMET - Instituto Nacional de Meteorologia (2015) Banco de Dados Meteorológicos para Ensino e Pesquisa. Available in: http://www.inmet.gov.br/portal/index.php?r=home/page\& page $=$ sobre_inmet. Accessed: Oct 15, 2015.

IPECE - Instituto de Pesquisa e Estratégia Econômica do Ceará (2018) Perfil municipal - Quixadá 2017. Governo do Estado do Ceará, 18p.

Köppen W (1918) Klassification der Klimate nach temperatur, niederschlag und jahreslauf. Gotha, Petermanns Geographische Mitteilungen 64:193-203.

Kotrba R, Knížková I, Kunc P, Bartoš L (2007)

Comparison between the coat temperature of the eland and dairy cattle by infrared thermography. Journal of Thermal Biology 32(6):355-359.

Mallick FH (1996) Thermal comfort and building design in the tropical climates. Energy and buildings 23(3):161-167.

Montanholi YR, Odongo NE, Swanson KC, Schenkel FS, McBride BW, Miller SP (2008) Aplicação da termografia infravermelha como indicador de produção de calor e metano e seu uso no estudo da temperatura da pele em resposta a eventos fisiológicos em bovinos leiteiros (Bos taurus). Journal of Thermal Biology 33(8):468-475.

Noronha RHF, Silva RP, Chioderoli CA, Santos Ep, Cassia MT (2011) Controle estatístico aplicado ao processo de colheita mecanizada diurna e noturna de canade-açúcar. Bragantia 70(4):931-938.

Pallotta M, Herdies DL, Gonçalves LGG (2015) Estudo das condições de tempo e conforto térmico no desempenho esportivo aplicado à maratona da Cidade do Rio de Janeiro. Revista Brasileira de Meteorologia 30(2):223-240.

Paranthaman D (1990) Controle de qualidade. São Paulo, McGraw-Hill, p118-212.

Ranjbarian S, Askari M, Jannatkhah J (2017) Performance of tractor and tillage implements in clay soil. Journal of the Saudi Society of Agricultural Sciences 16(2):154-162.

Roscani RC, Bitencourt DP, Maia PA, Ruas AC (2017) Risco de exposição à sobrecarga térmica para trabalhadores da cultura de cana-de-açúcar no Estado de São Paulo, Brasil. Cadernos de Saúde Pública 33(3):1-15. DOI: https://doi.org/10.1590/0102-311X00211415

Shi X, Zhu N, Zheng G (2013) The combined effect of temperature, relative humidity and work intensity on human strain in hot and humid environments. Building and environment 69:72-80. DOI:

https://doi.org/10.1016/j.buildenv.2013.07.016

Silva RP, Voltarelli MA, Cassia MT (2015) Controle de qualidade em operações agrícolas mecanizadas. Jaboticabal, SBEA, 244p.

Terjung RL, Clarkson P, Eichner ER, Greenhaff PL, Hespel PJ, Israel RG, Wagenmakers AJ (2000) American College of Sports Medicine roundtable. The physiological and health effects of oral creatine supplementation. Medicine \& Science Sports \& Exercise 32(3):706-717.

Zerbato C, Furlani CEA, Voltarelli MA, Bertonha RS, Silva RP (2014) Quality control to seeding systems and densities in peanut crop. Australian Journal of Crop Science 8(6):992-998. 